ELORE (ISSN 1456-3010), vol. 20 - 1/2013.

Julkaisija: Suomen Kansantietouden Tutkijain Seura ry.

[http://www.elore.fi/arkisto/1_13/kaarlenkaski_ung-lanki.pdf]

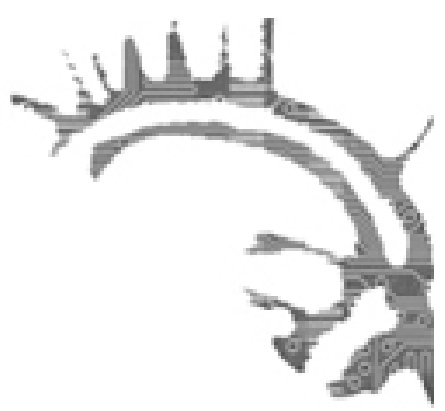

\title{
SAATteeksi
}

\section{IKKUNOITA IHMISTIETEELLISEEN ELÄINTUTKIMUKSEEN}

\author{
Taija Kaarlenkaski ja Sari Ung-Lanki
}

Yhteiskunta- ja kulttuuritieteellinen eläintutkimus (buman-animal studies) on kansainvälisesti vakiintunut, monitieteinen ja monimenetelmäinen tutkimusala, jota yhdistää teoreettisten ja menetelmällisten lähestymistapojen sijaan ennen kaikkea tutkimuskohde: ihmisen ja eläimen välinen suhde. Eläimet ovat olleet tutkimuksen kohteena ihmistieteissä aiemminkin, mutta yhteiskunta- ja kulttuuritieteellisen eläintutkimuksen näkökulmasta tarkastelun keskiöön nousee nimenomaan ihmisen ja eläimen välinen suhde, ei eläin sinänsä. Alalla tehtävä tutkimus keskittyy kuvaamaan, tulkitsemaan sekä kriittisesti tarkastelemaan esimerkiksi eläinten asemaa ja merkityksiä kulttuurissamme ja yhteiskunnassamme, eläinten representaatioita, ihmisen ja eläimen välistä vuorovaikutusta sekä eläinten toimijuutta. Tutkimuksen kohteet voivat olla konkreettisia tai symbolisia, todellisia tai fiktiivisiä, ja ne voivat sijoittua ajallisesti niin historiaan, nykypäivään kuin tulevaisuuteenkin. (Shapiro 2008.) Suomessa tutkimusalalla ei ole toistaiseksi vakiintunutta nimeä, vaan siihen on viitattu puhumalla niin ihmistieteellisestä kuin yhteiskuntatieteellisestäkin eläintutkimuksesta hieman tutkijan omasta tieteenalasta riippuen.

Kasvavan eläimiin liittyvän yhteiskunta-ja kulttuuritieteellisen kiinnostuksen taustalla on monia tekijöitä, muun muassa laajemmat muutokset eläinten asemassa ja merkityksessä länsimaisissa yhteiskunnissa sekä muutokset arvomaailmassa ja asenteissa eläimiä kohtaan. Ihmisten ja eläinten välisten suhteiden tarkastelulle on myös yhteiskunnallista tilausta, kun näissä suhteissa tapahtuneet muutokset sekä eläinkysymyksen politisoi- 
tuminen asettavat uudenlaisia haasteita esimerkiksi eläinten pidolle, lainsäädännölle ja asiantuntijuudelle, kuten Teittinen ja Ratamäki tässä teemanumerossa kirjoittavat.

Länsimaisessa ajattelussa ja kulttuuriperinteessä tapa määritellä eläimiä on ollut tiiviisti sidoksissa tapaan määritellä laajemmin luontoa (Birke 1994, 6). Yksinkertaistaen voitaneen sanoa, että ihmisen ja luonnon välistä suhdetta on modernina aikana hallinnut luonnon ja kulttuurin välisen rajan korostuminen, dualistinen ajattelutapa, jossa luonnon ja eläimen on nähty edustavan toiseutta, hallittua tai erotettua suhteessa kulttuuriin ja ihmiseen (Plumwood 1993; Williams 2003). Tämänkaltainen erottelu luonnon ja kulttuurin välillä on jossain määrin ongelmallinen niin materiaalisesti kuin kulttuurisestikin (Latour 1993), joten kenties osuvammin voidaan puhua modernille ajalle ominaisesta välineellisestä suhtautumisesta luontoon ja eläimeen.

Tim Ingold $(1988,4)$ on kuvannyt eläimyyden (animality) ja ibmisyyden (bumanity) suhdetta tunnistamalla kaksi toisilleen vastakkaista näkökulmaa eläimyyteen. Eläimyys voidaan määritellä yhtäältä tilana, jonka piiriin kuuluvat kaikki eläinkunnan edustajat ihmislaji mukaan lukien, mutta toisaalta myös tilana, joka on nimenomaan ihmisyyden vastakohta. Samanlaisuuden ja erilaisuuden teema toistuukin yleisesti erilaisissa tavoissa määritellä eläimiä ja ihmisiä (Birke 1994, 13). Me tunnistamme eläimissä jotain itsestämme ja koemme ymmärtävämme eläimiä, joiden kanssa elämme. Toisaalta etäännytämme niitä ihmisestä monin tavoin, esimerkiksi kohtelemalla eläimiä eri tavoin niiden käyttötarkoituksen perusteella tai välttämällä puhumista eläinten tunteista (Tovey 2002; Tuomivaara 2010). Nora Schuurman pohtii tarkemmin ihmisen ja eläimen välistä erontekoa tässä Eloressa kolumnissaan, jossa hän kirjoittaa antropomorfismista ja antroposentrismistä sekä niiden suhteesta eläintutkimukseen.

Ihmisyyden ja eläimyyden merkityksiä sekä ihmisen ja eläimen välistä rajaa määritellään koko ajan uudelleen niin tieteessä, julkisessa keskustelussa, kulttuurituotteissa, yhteiskunnallisissa käytännöissä kuin arkielämässäkin. Donna Haraway (1991) on tunnetussa tekstissään "Manifesti kyborgeille" todennut, että ihmisen ja eläimen välinen raja on läpikotaisin murrettu 1900-luvun loppupuolelle tultaessa, sillä biologisen sukulaisuuden lisäksi vaikuttaa siltä etteivät edes kieli, työkalujen käyttö, sosiaalinen käyttäytyminen tai mentaaliset toiminnot kuulu yksinomaan ihmisille. Pohdinnat eläinten moraalisesta arvosta ja eläinten kokemuksellisuudesta ovat laajentuneet eläinetiikan piiristä myös yhteiskunnalliseen keskusteluun (Aaltola 2004). Toisaalta oletus merkittävästä erosta ihmisen ja muiden eläinten välillä kuitenkin yhä perustelee eläinten käyttöä esimerkiksi tehomaatalouden tuotteina ja laboratorioiden tutkimusvälineinä. Ihmisen ja eläimen välistä suhdetta länsimaisessa kulttuurissa luonnehtiikin ambivalenttius: eläimet ovat yhtäältä äärimmäisen hellyyden ja toisaalta äärimmäisen hyväksikäytön kohteita (Franklin 1999).

\section{KOTIMAISEN TUTKIMUKSEN TAUSTOJA}

Suomalaisessa kulttuuri- ja yhteiskuntatieteellisessä tutkimuksessa eläimet ja niihin liittyvät kysymykset ovat alkaneet muotoutua omaksi erityiseksi tutkimuskohteekseen 
Taija Kaarlenkaski ja Sari Ung-Lanki: Ikkunoita inmistieteelliseen eläintutkimukseen

2000-luvun aikana. Tutkimusalan vahvistumisesta kertoo oman tieteellisen seuran, Yhteiskunnallisen ja kulttuurisen eläintutkimuksen seuran (YKES ry), perustaminen vuonna 2009. Seuran esittely löytyy tämän lehden ajankohtaista-osiosta. Perinnetieteissäkin eläimen paikka on aiemmin ollut tukevasti marginaalissa, vaikka esimerkiksi eläinsymboliikkaa ja -mytologiaa on tarkasteltu osana kansanuskoa (esim. Haavio 1959, 41-78; Haavio 1967; Pentikäinen 1995, 88-116; Sarmela 2007; Siikala 2012, 174-177, 365-394, 410-415). Tällöin tarkastelun keskiössä ovat kuitenkin olleet ensisijaisesti kulttuuri-ilmiöt, eivät eläimet, eläinsuhteet tai -representaatiot sinänsä.

Eläinaiheisen humanistisen tutkimuksen kotimaisena päänavaajana voi pitää Henni Ilomäen ja Outi Lauhakankaan (2002) toimittamaa artikkelikokoelmaa Eläin ihmisen mielenmaisemassa, jonka kirjoittajat edustavat monia tieteenaloja fysiologisesta eläintieteestä kulttuuriantropologiaan ja suomen kielestä filosofiaan. Kirjan julkaisun yhteydessä valmistui Terttu Kaivolan (2002) kokoama Eläin ja ihminen -bibliografia, jossa huomio kiinnittyy kotimaisen tutkimuskirjallisuuden vähäisyyteen. Kuluneessa reilussa kymmenessä vuodessa alan tutkimuksen määrä on meilläkin lisääntynyt huomattavasti. Ennen tätä Elorea Maaseudun uusi aika (toim. Ratamäki \& Schuurman 2007) sekä Alue ja ympäristö -lehdissä (toim. Ratamäki \& Salmi 2012) on julkaistu eläimiin keskittyvät teemanumerot. Molemmissa sekä toimitus- että kirjoittajavastuussa olivat pääasiassa yhteiskuntatieteilijät. Tämänkin numeron kirjoittajakunnassa on sekä kulttuuri- että yhteiskuntatieteilijöitä. Artikkelien yhdistävä piirre on ennen kaikkea eläinteeman tarkastelu laajasti katsottuna ihmistieteiden näkökulmasta, ei niinkään eri tieteenaloihin sitoutuvat teoreettiset tai metodiset lähtökohdat. Keskeisiä ovat ihmisten eläimille antamat merkitykset sekä ihmisten ja eläinten erilaiset vuorovaikutussuhteet, jotka voivat ilmetä niin teksteissä, kuvissa kuin haastattelupuheessakin.

\section{ELÄIMET KULTTUURINTUTKIMUKSEN KENTILLE}

Vuonna 2009 julkaistun artikkelikokoelman Ihmisten eläinkirja (toim. Kainulainen \& Sepänmaa) johdantotekstissä Pauliina Kainulainen $(2009,11)$ esittää, että "ihmistieteiden lisäarvo eläintutkimukselle on uusissa, yllättävissä tarkastelukulmissa ja niiden yhdistelmissä. Tällaisia uusia ja yllättäviä tarkastelukulmien yhdistelmiä tarjoaa myös tämä lehti. Ajallisesti ja tilallisesti artikkelit liikkuvat valtavan laajalla alueella: antiikin Kreikasta 1600-luvun Karibialle ja Venäjän Kaukoidästä Kanadan suurille karjatiloille. Myös tarkastelun kohteena olevat eläinsuhteet vaihtelevat konkreettisista ruumiillisista kontakteista kirjoitettuihin representaatioihin. Artikkelit osoittavat, että esimerkiksi kysymykset siitä, missä määrin eläimet ovat ihmisenkaltaisia ja missä tilanteissa niihin voi samaistua, ovat askarruttaneet mieliä monissa kulttuureissa. Useissa artikkeleissa pohditaan ja haastetaan myös luonnon ja kulttuurin sekä villin ja kesyn vastakkainasettelua.

Kuten Outi Ratamäki $(2010,417)$ on kirjoittanut, "[u]usi eläintutkimus haastaa tutkimaan eläinrepresentaatioita myös sen vuoksi, että saataisiin selville, mitä ne kertovat eläimestä, eläimen asemasta tai ihmisten suhteesta eläimiin”. Perinnetieteissä, kuten humanistisissa tieteissä yleensäkin, tutkimuksen kohteina ovat olleet ihmiset, heidän 
Taija Kaarlenkaski ja Sari Ung-Lanki: Ikkunoita inmistieteelliseen eläintutkimukseen

yhteisöllinen vuorovaikutuksensa ja kulttuurituotteensa. Ihmistieteellinen eläintutkimus tuo tutkimuksen kentälle myös eläimet subjekteina, yhteisöjen osina ja aktiivisina toimijoina, ja näin tarkastelukulmatkin laajenevat. Eläinten toimijuutta pohtii uskontotieteilijä Teuvo Laitila, joka soveltaa artikkelissaan uudelleen tulkittua animismin käsitettä. Siperian alkuperäiskansojen kertomuksissa amurintiikeri hahmottuu monin tavoin ihmisenkaltaisena persoonana, jonka kanssa voidaan kommunikoida ja joka jossain määrin jakaa yhteistä tilaa. Ihmisen kanssa kommunikoivat myös papukaijat, joiden kyky oppia tuottamaan puhetta on hämmästyttänyt ihmisiä vuosisatoja. Karibian alueen papukaijojen reittejä Eurooppaan tarkasteleva historiantutkija Laura Hollsten osoittaa, että näiden lintujen paikka yhtäältä ravintona, toisaalta seuraeläiminä oli varsin ristiriitainen.

Viime vuosina monilla humanistisilla aloilla, kuten taiteentutkimuksessa ja laajemmin kulttuurintutkimuksessa, on alettu kiinnittää huomiota materiaalisuuteen ja ruumiillisuuteen (ks. esim. Kontturi \& Tiainen 2004; Lehtonen 2005). Näitä lähestymistapoja voidaan hyödyntää myös tarkasteltaessa eläinsuhteita. Esimerkiksi Donna Haraway (2008) on kirjoittanut maailman materiaalis-semioottisesta rakentumisesta ja "luontokulttuureista". Antropologi Andrea Petitt tarkastelee artikkelissaan hevosten ja nautojen roolia kanadalaisessa cowboy-kulttuurissa. Hän kuvaa, kuinka erilaisia maskuliinisuuksia ja identiteettejä tuotetaan ihmisen ja eläimen välisessä arkisessa vuorovaikutuksessa ja materiaalisissa käytännöissä. Tiettyjen koirarotujen vaarallisuudesta käytyä keskustelua ja lainsäädäntöä artikkelissaan tarkasteleva Ane Möller Gabrielsen toteaa, että käsitykset "vaarallisesta koirasta" rakentuvat sekä diskursiivisesti että materiaalisesti. Hän kuvaa myös, kuinka eläimet ovat vahvasti läsnä yhteiskunnallisessa vallan ja hallinnan kontekstissa; yksittäisten koirarotujen hallinta laajenee koiranomistajien ja koko koiranpidon hallintaan.

Eläimistä karhu on Suomessa eniten saanut perinnetieteissä huomiota osakseen: sitä on käsitelty sekä osana mytologiaa ja kansanuskoa että nykyisenä kansallisena symbolina (esim. Klemettinen 2002; Pentikäinen 2005). Folkloristit Sofie Strandén-Backa ja Andreas Backa kohdistavat katseensa aivan toisen kokoluokan eläimeen, leppäkerttuun, ja tarkastelevat sen symbolisia merkityksiä ja käyttöä RKP:n logossa. Liisa Kaski taas yhdistelee folkloristiikan ja antiikintutkimuksen lähestymistapoja ja tutkii antiikin Kreikassa vuosisatoja ennen ajanlaskumme alkua kirjoitettua runoutta ja kasvatukseen kytkeytyviä riittejä, joihin meille tuttu karhukin kiinnostavasti kytkeytyy. Kaski osoittaa, että eläinoikeusajattelun ituja voi löytyä yllättävän kaukaa.

Toivotamme ajatuksia herättäviä lukuhetkiä niin ihmistieteelliseen eläintutkimukseen aiemmin perehtyneille kuin tutkimusalaan tämän numeron myötä tutustuvillekin!

\section{KirJallisuUs}

AALTOLA, ELISA 2004: Eläinten moraalinen arvo. Tampere: Vastapaino. BIRKE, LYNDA 1994: Feminism, animals and science. The naming of the shrew. Buckingham and Philadelphia: Open University Press.

FRANKLIN, ADRIAN 1999: Animals and modern cultures. A sociology of humananimal relations in modernity. London: Sage. 
Taija Kaarlenkaski ja Sari Ung-Lanki: Ikkunoita inmistieteelliseen eläintutkimukseen

HAAVIO, MARTTI 1959: Karjalan jumalat. Uskontotieteellinen tutkimus. Helsinki: WSOY.

- 1967: Suomalainen mytologia. Helsinki: WSOY.

HARAWAY, DONNA 1991: Simians, cyborgs, and women. The reinvention of nature. London: Free Association Books.

- 2008: When Species Meet. Minneapolis: University of Minnesota Press.

ILOMÄKI, HENNI \& LAUHAKANGAS, OUTI (toim.) 2002: Eläin ihmisen mielenmaisemassa. Helsinki: SKS.

INGOLD, TIM (ed.) 1988: What is an animal? London: Unwin Hyman.

KAINULAINEN, PAULIINA 2009: Johdanto. Ihmistieteiden anti eläintutkimukselle. - Pauliina Kainulainen \& Yrjö Sepänmaa (toim.), Ihmisten eläinkirja. Muuttuva eläinkulttuuri. Helsinki: Gaudeamus Helsinki University Press.

KAIVOLA, TERTTU 2002: Eläin ja ihminen: kulttuuriantropologista, folkloristista ja uskontotieteellistä kirjallisuutta: bibliografia [online]. < http://www.finlit.fi/kirjasto/ julkaisu/elain2.pdf $>$ [25.3.2013.]

KLEMETTINEN, PASI 2002: Kurkistuksia karhun kulttuurihistoriaan. - Henni Ilomäki \& Outi Lauhakangas (toim.), Eläin ihmisen mielenmaisemassa. Helsinki: SKS.

KONTTURI, KATVE-KAISA \& TIAINEN, MILLA 2004: Taiteentutkimus ja materiaalisuuden haaste. Feministisiä suunnanavauksia. - Kulttuurintutkimus 21(3).

LATOUR, BRUNO 1993: We Have Never Been Modern. Cambridge, Mass.: Harvard University Press.

LEHTONEN, MIKKO 2005: Ruumiin ylösnousemus - ja sen haasteet tutkimukselle. - Kulttuurintutkimus 22(2).

PENTIKÄINEN, JUHA 1995: Saamelaiset - pohjoisen kansan mytologia. Helsinki: SKS.

- 2005: Karhun kannoilla. Metsänpitäjä ja mies. Helsinki: Etnika.

PLUMWOOD, VAL 1993: Feminism and the mastery of nature. London and New York: Routledge.

RATAMÄKI, OUTI 2010: Katsaus yhteiskunnallisen ja kulttuurisen eläintutkimuksen tieteenalaan. - Ympäristöpolitiikan ja -oikeuden vuosikirja 4.

RATAMÄKI, OUTI \& SCHUURMAN, NORA (toim.) 2007: Teemana eläimet. Elinkeinot, harrastukset, hyvinvointi ja muutos. - Maaseudun uusi aika 15(2).

RATAMÄKI, OUTI \& SALMI, PEKKA (toim.) 2012: Eläimet lähellämme. - Alue ja ympäristö 41(2).

SARMELA, MATTI 2007: Suomen perinneatlas. Suomen kansankulttuurin kartasto 2. Kolmas, osittain uusittu painos [online].< http://www.kolumbus.fi/matti.sarmela/ Suomen perinneatlas.pdf $>$ [26.3.2013].

SHAPIRO, KENNETH 2008: Human-animal studies. Growing the field, applying the field. Ann Arbor: Animals and Society Institute.

SIIKALA, ANNA-LEENA 2012: Itämerensuomalaisten mytologia. Helsinki: SKS.

TOVEY, HILARY 2002: Risk, morality and the sociology of animals: Reflections on the Foot and Mouth outbreak in Ireland. - Irish Journal of Sociology 11(1).

TUOMIVAARA, SALLA 2010: Eläimet - luonnon ja yhteiskunnan rajoilla. - Jarno Valkonen (toim.), Ympäristösosiologia. Helsinki: WSOY. 
Taija Kaarlenkaski ja Sari Ung-Lanki: Ikkunoita inmistieteelliseen eläintutkimukseen

WILLIAMS, RAYMOND 2003: Luontokäsitykset. - Yrjö Haila \& Ville Lähde (toim.), Luonnon politiikka. Tampere: Vastapaino.

Filosofian tohtori Taija Kaarlenkaski tekee perinteentutkimuksen post doc -tutkimusta Itä-Suomen yliopistossa.

Yhteiskuntatieteiden maisteri Sari Ung-Lanki valmistelee sosiologian alan väitöskirjaa Jyväskylän yliopistossa. 